\title{
RADIOCARBON DATING OF MUMMIFIED HUMAN REMAINS: APPLICATION TO A SERIES OF COPTIC MUMMIES FROM THE LOUVRE MUSEUM
}

\author{
Pascale Richardin $^{1,2}$ • Magali Coudert ${ }^{3}$ • Nathalie Gandolfo ${ }^{1} \bullet$ Julien Vincent $^{1}$
}

ABSTRACT. Many French museums keep in their reserves a great number of mummified human remains. Beyond any ethical or deontological issues, they constitute an important part of our archaeological and historical heritage. Their dating is often inexact and imprecise, but nevertheless this parameter is very interesting, especially if correlated or associated with other analytical or typological data, e.g. the process of mummification. The present study has been carried out in the context of a multidisciplinary scientific program on a set of Coptic mummies found at the site of Antinoe (Egypt), deposited in the Louvre Museum or sent by the state to various other French museums. To minimize the sample size, we have developed a new method for the pretreatment of hair samples before accelerator mass spectrometry (AMS) radiocarbon dating. Thus, we have taken samples from $~ 30$ mummies, distributed in 8 museums around France, and also from different textiles or plants near or on the bodies. The results and conclusions show the importance of dating mummies in a museum context. For example, ${ }^{14} \mathrm{C}$ dates permit the exclusion of the assumed relationship of a woman with a child. Similarly, a hair sample from the head of a mummy presents a very different ${ }^{14} \mathrm{C}$ date from that of the hair across her chest. The results show that these hairs came from another mummy and were probably placed there intentionally by the people in charge of the collections.

\section{INTRODUCTION}

Many French museums — of art, archaeology, ethnography, anatomy, and even natural history— keep in their reserves a great number of mummified human remains. Beyond any ethical or deontological issues that arise with such collections, it is evident that these human bodies constitute an important part of our archaeological and historical heritage (Cadot 2007). The mission of a curator or anyone in charge of mummies is not only to preserve them, but also to undertake historical or scientific research with the aim of obtaining an insight into their origin, the process of mummification (e.g. Lucejko et al. 2012), their diet (Bocherens 2010), and simply to answer the following questions: who were these people, where did they come from, or how were the mummies collected? However, in most cases, all the documentation has disappeared and thus, now out of context, these mummies lose their interest to the scientific community.

This work takes place in a broader project set up by the Service du Récolement des Dépôts Antiques et des Arts de l'Islam from the Louvre Museum. In 2010, an historical, scientific, and archaeological study was undertaken on the collections from the Egyptian site of Antinoe-excavated by French archaeologist Albert Gayet between 1895 and 1910 - and dispatched throughout France and some European and non-European countries. This multidisciplinary program is carried out on 2 studied groups: the mummies (a set of 39 individuals) and several textiles. The research is conducted along 3 connected areas: 1 ) clarifying the chronology not well established until now (Roman-Byzantine, Roman, and Byzantine as appropriate); 2) genetic and anthropological studies; and 3) understanding of burial practices (Lintz and Coudert 2013).

Direct dating of human remains is essential for placing the individuals in a chronological and culturally reliable system. The dating of mummies is often inexact and imprecise, but nevertheless this information would be very interesting if it could be correlated with other chronological or analytical

\footnotetext{
${ }^{1}$ Centre de Recherche et de Restauration des Musées de France, C2RMF, Palais du Louvre, Porte des Lions, 14 quai François Mitterrand, 75001 Paris, France.

${ }^{2}$ Corresponding author. Email: pascale.richardin@culture.gouv.fr.

${ }^{3}$ Service du Récolement des Dépôts Antiques et des Arts de l’Islam (SRDAI), Musée du Louvre, Pavillon Mollien, 75001 Paris, France.
} 


\section{P Richardin et al.}

data, e.g. their clothing. The radiocarbon method is generally used and applied to the residual collagen extracted from bones (Bronk Ramsey et al. 2004) or other biological tissues, such as skin (van der Plicht et al. 2004; Van Strydonck et al. 2009) or dental enamel (Wild et al. 2007; Porto et al. 2011; Beavan et al. 2012). However, this approach is very limited or even inconceivable when it concerns the study of mummies from museum collections. Indeed, the required sampling is far too invasive and destructive, even if measurements are performed by accelerator mass spectrometry (AMS). Therefore, we recently developed a new protocol for the pretreatment of hair samples that differs from the classical AAA protocol (van der Plicht et al. 2004), based on the selective extraction of keratin cortex (Richardin et al. 2011), and requires only $30 \mathrm{mg}$ or less of raw material. This method discards the proteins of the cuticle (outer part of the hair) that could contain external contaminants, and is now applied for routine mummy dating.

We took hair samples from 26 of the mummies selected for study (Figure 1). For the other specimens, hair was inaccessible (totally wrapped mummies) or too sparse (mummies of babies or young children). Whenever possible, we also studied samples that could be from the funerary material of the mummy (leaves, wood fragments, reeds) and textiles from clothing, in order to check whether or not they are associated with the corpses (Sowada et al. 2011). A set of more than 100 samples (hair, vegetal, and textiles) have been collected and dated (Richardin et al. 2013).

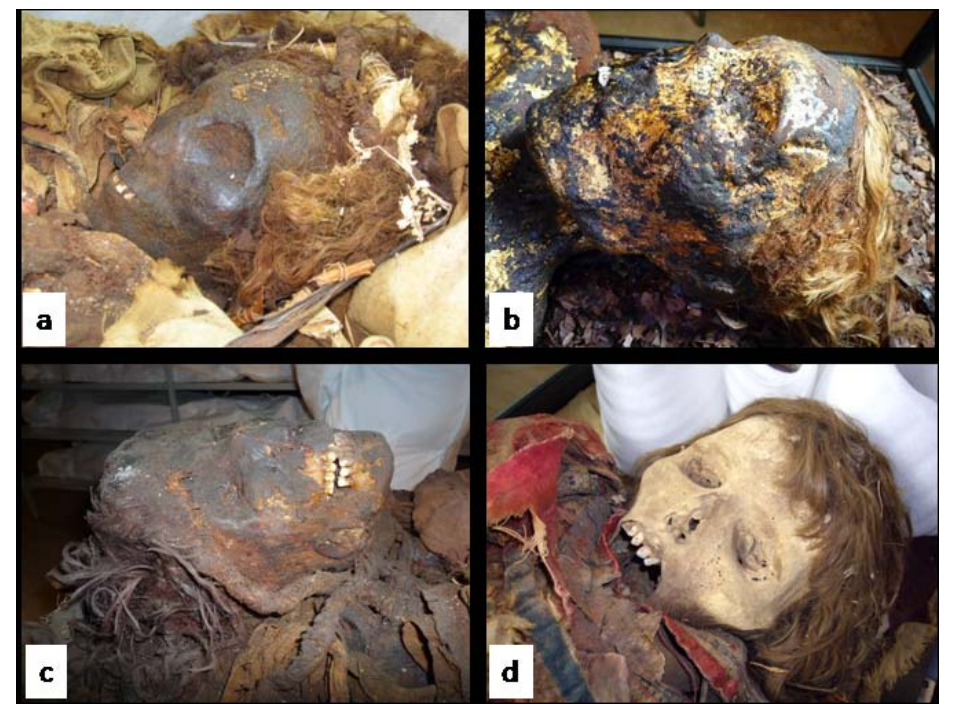

Figure 1 Photographs of 4 mummies, showing the diversity of processes of mummification and the hair aspect and/or color. a) Mummy of the Isiac Priestess (Inv. BF 3644), Museum of Art and Archaeology Joseph Denais, Beaufort-en-Vallée; b) Mummy of the Prophetess (Inv. BA 1972.00.151), Museum of Fine Arts, Dunkerque; c) Mummy of a woman with her baby (Inv. 90002977A), Museum of Confluences, Lyon; d) Mummy of a man with a red coat, Museum of Fine Arts, Lille.

\section{EXPERIMENTAL}

\section{Sampling}

During this project, we have collected hair samples from the mummies in their place of storage or display, except for one of the mummies that was being restored at C2RMF Versailles. Hair (between 30 and $100 \mathrm{mg}$ ) was sampled with small pliers or very small scissors. 
${ }^{14} \mathrm{C}$ Dating of Mummified Human Remains

\section{Infrared Spectroscopy}

Infrared spectra were recorded using a FTIR spectrometer Spectrum 2000 from PerkinElmer, with a Golden Gate ${ }^{\mathrm{TM}}$ ATR accessory, from Specac. It is a single reflection monolithic diamond ATR system, which allows the direct analysis of fibers without any sample preparation. Infrared spectra were collected with an accumulation of 20 scans in the range from 400 to $4000 \mathrm{~cm}^{-1}$ and a resolution of $4 \mathrm{~cm}^{-1}$. All data were processed with the Spectrum software.

\section{Sample Preparation}

\section{Cleaning and Solvent Extraction}

In order to eliminate all sources of mineral or organic contamination due to contact with sediments, organic matter, or biological fluids (mummification balms, adipocerous or other decomposition fluids, varnishes, or synthetic resins), all samples were washed with ultrapure water (Direct-Q system from Millipore), then with a mixture of methanol/dichloromethane (1/1), and finally with acetone (AnalaR Normapur, from VWR International) in a ultrasonic bath. After each treatment, samples were thoroughly rinsed 3 times with ultrapure water.

Plant Samples (Wood, Plant Fibers, Leaves, Linen)

Plant samples have been treated with the well-established AAA method (Richardin et al. 2010a,b). This consisted of a series of washings at $80{ }^{\circ} \mathrm{C}$ for $1 \mathrm{hr}$ with a $0.5 \mathrm{M}$ hydrochloric acid solution (VWR International), followed by a $0.01 \mathrm{M} \mathrm{NaOH}$ aqueous solution (VWR International), and once again with the $0.5 \mathrm{M}$ hydrochloric acid solution. Before each treatment, the supernatant was removed with a glass pipette and the remaining fragments rinsed with ultrapure water until neutrality of the washing waters. Finally, the clean samples were dried overnight in a low-vacuum (100 mbar) oven at $60^{\circ} \mathrm{C}$.

\section{Hair and Wool Samples}

The protocol for preparation of hair samples that we have developed is based on the selective extraction of keratin from the cortex by reduction using dithiothreitol, followed by the precipitation of the extract in the presence of sodium deoxycholate (DCO) and trichloroacetic acid (TCA). The method has been previously described in detail (Richardin et al. 2011). Briefly, 30-50 mg of hair samples are immersed in an extraction solution without agitation for 1 to 3 days at $50^{\circ} \mathrm{C}$. This solution consists of DL-dithiothreitol (at $10 \mathrm{mg} / 100 \mathrm{~mL}$ in water) in a mixture of sodium dodecyl sulfate (at $10 \mathrm{mg} /$ $100 \mathrm{~mL}$ in water) and Tris- $\mathrm{HCl}$ (solution $0.5 \mathrm{M}, \mathrm{pH}$ 8, Sigma). After extraction, the solution is filtered on quartz-fiber paper and the proteins are purified by precipitation with $60 \mu \mathrm{L}$ of a sodium deoxycholate solution $(0.2 \mathrm{mg} / 10 \mathrm{~mL}$ in water) and $600 \mu \mathrm{L}$ of a trichloroacetic acid solution (1 mg/ $\mathrm{mL}$ in water). After centrifugation, proteins are washed with $10 \mathrm{~mL}$ of acetone at low temperature. Finally, the precipitate is repeatedly rinsed with ultrapure water and dried by lyophilization.

\section{Combustion and Graphitization}

The organic fraction was then combusted at high temperature $\left(5 \mathrm{hr}\right.$ at $\left.850{ }^{\circ} \mathrm{C}\right)$ under high vacuum (at $10^{-6}$ Torr) on a semiautomatic combustion bench. Some 2-2.5 $\mathrm{mg}$ of the processed samples were combusted in a quartz tube with $500 \mathrm{mg} \mathrm{CuO} \mathrm{(for} \mathrm{analysis,} \mathrm{from} \mathrm{VWR} \mathrm{International)} \mathrm{and} \mathrm{a} \mathrm{piece} \mathrm{of}$ silver wire (99.95\%, from Aldrich). The combustion gases were separated, and the $\mathrm{CO}_{2}$ was collected in a sealed tube. Graphitization of the $\mathrm{CO}_{2}$ gas obtained was performed by direct catalytic reduction with hydrogen, using Fe powder as a catalyst at $600^{\circ} \mathrm{C}$ and with an excess of $\mathrm{H}_{2}$. During 


\section{P Richardin et al.}

this process, the carbon is deposited on the iron. The entire powder is then mechanically pressed into a flat pellet. Before measurement, the graphite pellets are stored in a sealed tube under argon atmosphere.

\section{Radiocarbon Measurements and Calibration}

All measurements have been performed at the Artemis AMS (NEC, National Electrostatics Co.) facility at Saclay, France (Cottereau et al. 2007). The ${ }^{14} \mathrm{C}$ activity is calculated by comparing the measured intensities of the ${ }^{14} \mathrm{C},{ }^{13} \mathrm{C}$, and ${ }^{12} \mathrm{C}$ beams from each sample to those of $\mathrm{CO}_{2}$ standards prepared with HOx (I) oxalic acid reference, in pMC, normalized to $\delta^{13} \mathrm{C}=25 \%$ o (wood). The ${ }^{14} \mathrm{C}$ ages (in yr BP) are calculated after correction of the isotope fractionation $\delta^{13} \mathrm{C}$ measured by AMS.

Calendar ages are determined using the CALIB rev 6.0.0 (Stuiver and Reimer 1993) or OxCal v 4.1 programs (Bronk Ramsey 2009) and the terrestrial calibration curve IntCal09 (Reimer et al. 2009). Calibrated age ranges correspond to $95.4 \%$ probability $(2 \sigma)$ and are expressed in cal BC/AD.

\section{RESULTS AND DISCUSSION}

Before ${ }^{14} \mathrm{C}$ dating the textiles, evaluating their degree of contamination and especially their nature (animal or plant) is essential when selecting the adequate pretreatment. Therefore, all the textiles were analyzed by FTIR attenuated total reflectance (Cybulska et al. 2008), after an initial wash with water in an ultrasonic bath to remove all mineral contamination.

Textiles such as wool or silk are proteins and their infrared spectra present characteristic absorption bands. The 2 strong bands at around $1650 \mathrm{~cm}^{-1}$ (amide I) and $1550 \mathrm{~cm}^{-1}$ (amide II) are typical protein bands that arise mainly from $\mathrm{C}=\mathrm{O}$ stretching and $\mathrm{N}-\mathrm{H}$ bending vibrations, respectively, of amide groups of the peptide backbone (Jackson and Mantsch 1995). Among the infrared bands obtained for plant-based textiles (e.g. linen, cotton), we selected the 2 bands at 1110 and $1060 \mathrm{~cm}^{-1}$ (Figure 2) as a characteristic and selective test to assign the cellulosic nature of a textile (assigned to $\mathrm{C}-\mathrm{O}$ bridge stretching and $\mathrm{C}-\mathrm{O}-\mathrm{C}$ pyranose ring skeletal vibration in cellulose compounds) (Garside and Wyeth 2003; El-Gaoudy et al. 2011). Thus, of the 17 textile fragments, only 2 were wool, the 15 others linen. The latter will be treated like plant samples.

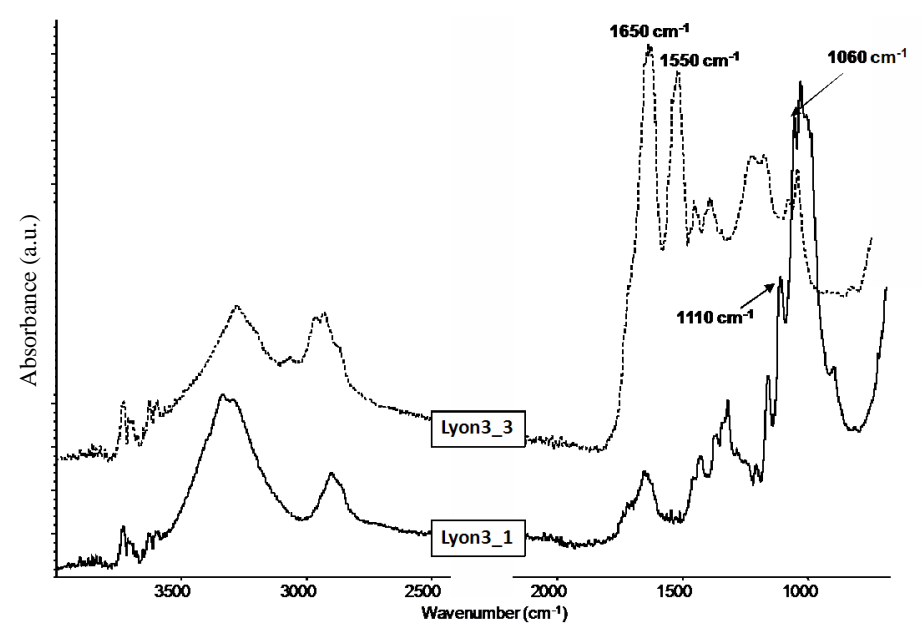

Figure 2 FTIR spectra of 2 textile samples from the mummy "Phaank woman" (Museum of Confluences, Inv. 90001594). Lyon3_3 is a wool sample and Lyon3_1 is linen. 


\section{${ }^{14} \mathrm{C}$ Dating of Mummified Human Remains}

The ${ }^{14} \mathrm{C}$ ages and calibrated calendar age ranges of the individual samples are given in Table S1 (online Supplementary file). Good reproducibility of the results for the plant samples and hair samples can be observed, e.g. a wood sample from the mummy "Myritis" (Inv. 23735, Museum of Man, Paris), MYR_1: $1785 \pm 30$ and $1790 \pm 30$ yr BP; or a hair sample from the mummy "Phaank woman" (Inv. 90001594, Museum of Confluences, Lyon), LYON3_5: $1900 \pm 30$ and $1920 \pm 30$ yr BP.

The values obtained for hair are grouped and calibration results are shown in Figure 3. These results confirm the classification of mummies into the 2 periods of Coptic Egypt (Aubert and Rutschowscaya 1997): the Roman period (1st century to the end of the 4th century AD) and the Byzantine period (5th-7th century AD). Thus, for the whole suite, 7 mummies are considered from the Roman period: the black mummy (Inv. 23313, Museum of Man, Paris); the mummy of the Prophetess (Inv. BA 1972.00.151, Museum of Fine Arts, Dunkerque); a male mummy (Inv. 4026, Museum of Art and Archaeology from the Perigord, Perigueux); 3 female mummies (Inv. 90001594, 90002980, and 90002978, Museum of Confluences, Lyon); and the mummy of the Isiac Priestess (Inv. BF3644, Museum of Art and Archaeology Joseph Denais, Beaufort-en-Vallée). The other 19 mummies are from the Byzantine period.

We also observed a surprising result concerning the funerary practices of this suite of samples. Indeed, the "mummy of a woman with a baby" (Inv. 90002977A, Museum of Confluences, Lyon), is a so-called "black" mummy, thought to be coated with bitumen. The dating of the hair (LYON6_1: $1270 \pm 30$ and $1275 \pm 30$ yr BP) shows that it is a Byzantine mummy. This funerary practice, which was commonly observed in the treatment of bodies during the Roman period, would thus have lasted for a longer time, until at least the 7th century AD.

At the Museum of Confluences, the mummy of a woman (Inv. 90002978) is displayed next to that of a child. The ${ }^{14} \mathrm{C}$ dates obtained for the hair of the 2 mummies are very different: for the woman (LYON5_2), $1690 \pm 30$ and $1680 \pm 30$ yr BP, and for the child (LYON5_1), $1540 \pm 30$ and $1525 \pm$ $30 \mathrm{yr}$ BP. These results confirm that these mummies are not a mother and her child, but that this combination is rather a staging done by the curators or even by the archaeologist himself. From the female mummy "The Diounesast” (Inv. 90002430, Museum of Confluences), we took 2 hair samples. The dates of the hair sampled on the head (LYON7_4) are $1630 \pm 30$ and $1680 \pm 30 \mathrm{yr}$ BP, while those collected along the body (LYON7_6) are $1195 \pm 30$ and $1235 \pm 30 \mathrm{yr}$ BP. Thus, the 2 samples cannot come from the same person. This conclusion has been also confirmed by isotopic values obtained on the same samples (H Bocherens, D Drucker, unpublished data).

In other cases, we had the chance to take samples from a few objects around the body (e.g. leaves, wood fragments, textiles, etc.). Some of these samples were contemporary to the mummy and can therefore be considered part of the funerary materials. For example, the ${ }^{14} \mathrm{C}$ dates of the hair samples of the mummy Inv. 1448 from the Museum of Anatomy Testut Latarjet, Lyon (LYON2_4: $1525 \pm$ 30 and $1540 \pm 30 \mathrm{yr}$ BP) are identical to those obtained for the vegetal braided mat deposited along the body (LYON2_2: $1525 \pm 30$ and $1530 \pm 30 \mathrm{yr}$ BP). Sometimes, the dates are very different, though, and thus exclude any relationship. This is the case for a small plant fragment collected near the mummy of the Prophetess from Dunkerque (DUNK_4) with a date of $1585 \pm 30 \mathrm{yr}$ BP with a date for the hair that is much older (DUNK_3, $1785 \pm 30$ yr BP and DUNK_10, $1775 \pm 30$ and $1765 \pm 30$ yr BP). 


\section{P Richardin et al.}

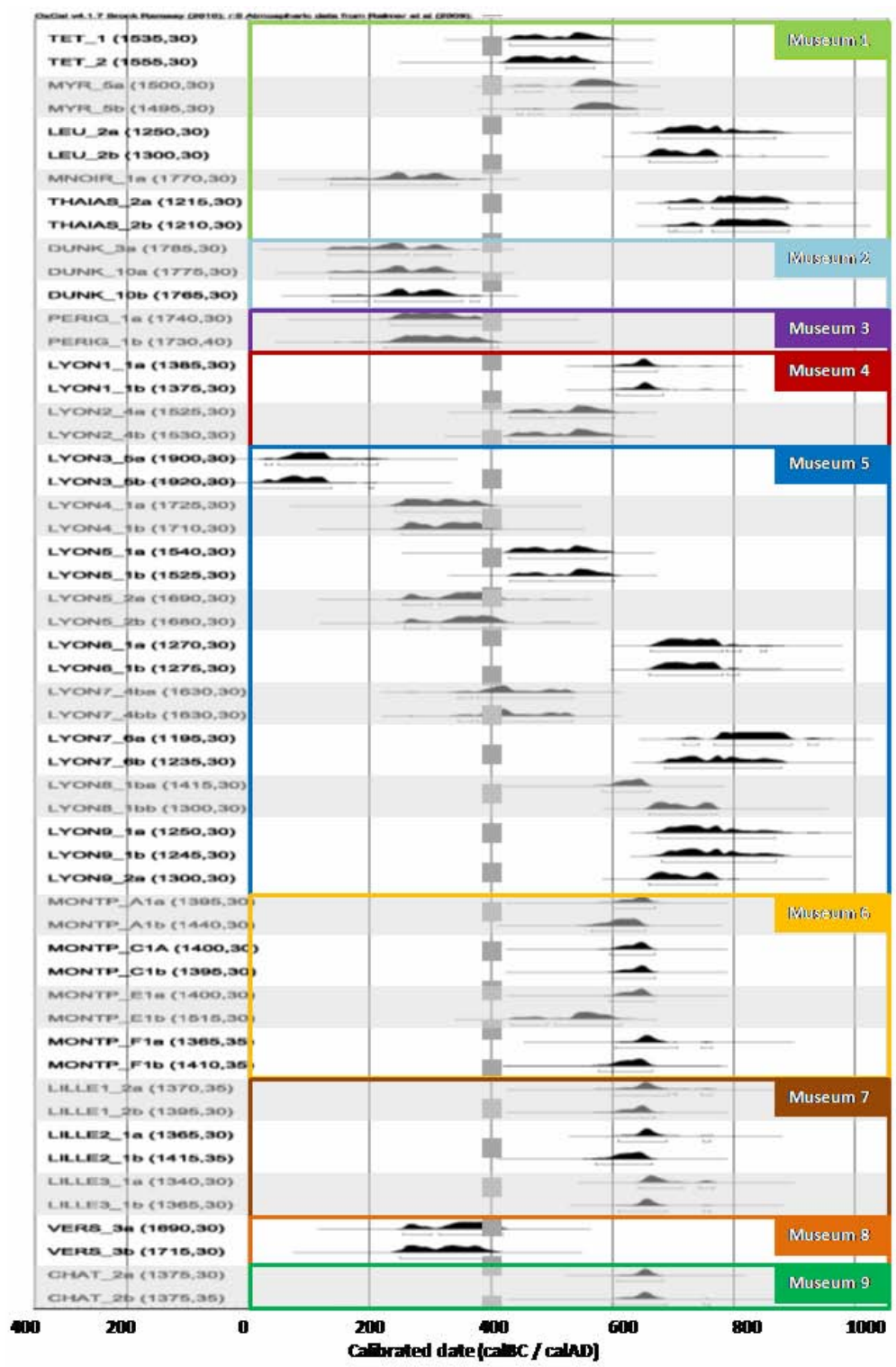

Figure 3 Calibrated ${ }^{14} \mathrm{C}$ ages for all the hair samples. Museum 1: Museum of Man, Paris; Museum 2: Museum of Fine Arts, Dunkerque; Museum 3: Museum of Art and Archaeology of Périgord, Périgueux; Museum 4: Museum of Anatomy Testut-Latarjet from the Faculty of medicine, Lyon; Museum 5: Museum of Confluences, Lyon; Museum 6: Museum of Anatomy from the Faculty of Medicine, Montpellier; Museum 7: Museum of Fine Arts, Lille; Museum 8: Museum Joseph Denais, Beaufort-en-Vallée; and Museum 9: Museum of Bertrand hotel, Châteauroux. The dotted horizontal line corresponds to the boundary between the Roman and Byzantine periods.

\section{CONCLUSION}

These ${ }^{14} \mathrm{C}$ dating results confirm the classification of a set of Coptic mummies in the 2 periods of Coptic Egypt: the Roman period (1st century to end of 3rd century AD) and Byzantine period (late 


\section{${ }^{14} \mathrm{C}$ Dating of Mummified Human Remains}

3rd to 7th century AD). We also observed an interesting result concerning the funerary practice on a Byzantine mummy that was covered with bitumen. This funerary practice, commonly used during the Roman period, would therefore have lasted at least up to the 7th century AD.

${ }^{14} \mathrm{C}$ dating has also confirmed the attribution of funerary material, sometimes blurred by frequent staging of museum mummies at the beginning of the 20th century, by the curators or even by the archaeologists themselves. Similarly, we have demonstrated that a child was associated with a woman who was not his mother, thus solving a relationship question in this case. We are continuing this study with a large number of mummies found in French and foreign museums.

\section{ACKNOWLEDGMENTS}

We want to thank all the curators or collection managers who welcomed us warmly, trusted us, and allowed us to take samples. We especially wish to thank Aude Shoemaker, Karine Madrigal, Fleur Morfoisse-Guenault, Michele Naturel, Anne Raggi, Claude Steen, Sophie Warlop, Sophie Weygand, and also Francis Couturas, Alain Froment, Philippe Mennecier, François Michaud, and Christophe Neidhardt. We also thank Christophe Moreau and his team from the Laboratory of Measurement of Carbon 14 (LMC14 - UMS2572) for the graphitization of the gas samples and the ${ }^{14} \mathrm{C}$ measurements.

\section{REFERENCES}

Aubert M, Rutschowscaya M. 1997. In: Réunion des Musées Nationaux, Guide du visiteur. Musée du Louvre, editor. Les antiquités égyptiennes, tome 2. Egypte romaine, art funéraire et antiquités coptes. Paris: Musée du Louvre.

Beavan N, Halcrow S, MacFadgen B, Hamilton D, Buckley B, Sokla T, Shewan L, Sokha O, Fallon S, Miksic J, Armstrong R, O’Reilly D, Domett K, Chhem KR. 2012. Radiocarbon dates from jar and coffin burials of the Cardamom Mountains reveal a unique mortuary ritual in Cambodia's Late to Post-Angkor period (15th-17th centuries AD). Radiocarbon 54(1):1-22.

Bocherens H. 2010. Isotopic analysis of keratin-information about living environment and nutrition. In: Wieczorek A, Tellenbach M, Rosendahl W, editors. Mummies of the World: The Dream of Eternal Life. Munich: Prestel Verlag. p 232-5.

Bronk Ramsey C. 2009. Bayesian analysis of radiocarbon dates. Radiocarbon 51(1):337-60.

Bronk Ramsey C, Higham T, Bowles A, Hedges R. 2004. Improvements to the pretreatment of bone at Oxford. Radiocarbon 46(1):155-63.

Cadot L. 2007. Les restes humains: une gageure pour les musées? La Lettre de l'OCIM 109:5-15.

Cottereau E, Arnold M, Moreau C, Baqué D, Bavay D, Caffy I, Comby C, Dumoulin JP, Hain S, Perron M, Salomon J, Setti V. 2007. Artemis, the new ${ }^{14} \mathrm{C}$ AMS at LMC14 in Saclay, France. Radiocarbon 49(2):2919.

Cybulska M, Jedraszek-Bomba A, Kuberski S, Wrzosek H. 2008. Methods of chemical and physicochemical analysis in the identification of archaeological and historical textiles. Fibres \& Textiles in Eastern Europe
16(5):67-73.

El-Gaoudy H, Kourkoumelis N, Varella E, Kovala-Demertzi D. 2011. The effect of thermal aging and color pigments on the Egyptian linen properties evaluated by physicochemical methods. Applied Physics A 105(2):497-507.

Garside P, Wyeth P. 2003. Identification of cellulosic fibres by FTIR spectroscopy: thread and single fibre analysis by attenuated total reflectance. Studies in Conservation 48(4):269-75.

Jackson M, Mantsch HH. 1995. The use and misuse of FTIR spectroscopy in the determination of protein structure. Critical Reviews in Biochemistry and Molecular Biology 30(2):95-120.

Lintz Y, Coudert M. 2013. Collections égyptiennes d'Antinoé (Momies, tissus, céramiques et autres antiques)Envois de l'Etat et dépôts du musée du Louvre (18951925). Paris: Musée du Louvre. In press.

Lucejko JJ, Lluveras-Tenorio A, Modugno F, Ribechini E, Colombini MP. 2012. An analytical approach based on X-ray diffraction, Fourier transform infrared spectroscopy and gas chromatography/mass spectrometry to characterize Egyptian embalming materials. Microchemical Journal 103:110-8.

Porto IM, Laure HJ, Tykot RH, de Sousa FB, Rosa JC, Gerlach RF. 2011. Recovery and identification of mature enamel proteins in ancient teeth. European Journal of Oral Sciences 119(1):83-7.

Reimer PJ, Baillie MGL, Bard E, Bayliss A, Beck JW, Blackwell PG, Bronk Ramsey C, Buck CE, Burr GS, Edwards RL, Friedrich M, Grootes PM, Guilderson TP, Hajdas I, Heaton TJ, Hogg AG, Hughen KA, Kaiser KF, Kromer B, McCormac FG, Manning SW, Re- 


\section{P Richardin et al.}

imer RW, Richards DA, Southon JR, Talamo S, Turney CSM, van der Plicht J, Weyhenmeyer CE. 2009. IntCal09 and Marine09 radiocarbon age calibration curves, 0-50,000 years cal BP. Radiocarbon 51(4): 1111-50.

Richardin P, Gandolfo N, Moignard B, Lavier C, Moreau C, Cottereau E. 2010a. Centre of Research and Restoration of the Museums of France: AMS radiocarbon dates list 1. Radiocarbon 52(4):1689-700.

Richardin P, Cuisance F, Buisson N, Asensi-Amoros V, Lavier C. 2010b. AMS radiocarbon dating and scientific examination of high historical value manuscripts: application to two Chinese manuscripts from Dunhuang. Journal of Cultural Heritage 11(4):398-403.

Richardin P, Gandolfo N, Carminatti P, Walter P. 2011. A new protocol for radiocarbon dating of hair and keratin type samples-application to an Andean mummy from the National Museum of Natural History in Paris. Archaeological and Anthropological Sciences 3(4): 379-84.

Richardin P, Coudert M, Gandolfo N, Vincent J. 2013. Datation par le radiocarbone: étude chronologique des momies et de leur matériel funéraire. In: Lintz Y,
Coudert M, editors. Collections égyptiennes d'Antinoé (Momies, tissus, céramiques et autres antiques) Envois de l'Etat et dépôts du musée du Louvre (18951925). Paris: Musée du Louvre. In press.

Sowada K, Jacobsen GE, Bertuch F, Palmer T, Jenkinson A. 2011. Who's that lying in my coffin? An imposter exposed by ${ }^{14} \mathrm{C}$ dating. Radiocarbon 53(2):221-8.

Stuiver M, Reimer PJ. 1993. Extended ${ }^{14} \mathrm{C}$ data base and revised CALIB $3.0{ }^{14} \mathrm{C}$ age calibration program. $\mathrm{Ra}$ diocarbon 35(1):215-30.

van der Plicht J, Van der Sanden WAB, Aerts AT, Streurman HJ. 2004. Dating bog bodies by means of ${ }^{14} \mathrm{C}$ AMS. Journal of Archaeological Science 31(4):47191.

Van Strydonck M, De Moor A, Benazeth D. $2004 .{ }^{14} \mathrm{C}$ dating compared to art historical dating of Roman and Coptic textiles from Egypt. Radiocarbon 46(1):23144.

Wild EM, Guillen S, Kutschera W, Seeidler H, Steier P. 2007. Radiocarbon dating of the Peruvian Chachapoya/Inca site at the Laguna de los Condores. Nuclear Instruments and Methods in Physics Research B 259(1):378-83. 